\title{
Developing Reading Skills in Beginning Readers in Nigerian Primary Schools towards the Millennium Development Goals
}

\author{
Jeno-Mary Enighe \\ Faculty of Education, University of Jos, Nigeria \\ Maria Emmanuel Afangideh \\ Faculty of Education, University of Uyo, Nigeria
}

\begin{abstract}
Against the objective of the Millennium Development Goals (MDGs), this study investigated impediments to the reading competence of primary school learners in Akwa Ibom State of Nigeria. The objective was to determine how reading approaches such as pointing at words, vocalization and subvocalization, excessive eye fixation, regression as well as involvement in extensive reading and teachers' instructional techniques relate with the academic performance of learners at the basic education level. The study which employed a simple survey design raised three hypotheses as a guide, while 200 pupils selected through a stratified random sampling technique responded to an achievement test of a 12-item questionnaire. The resulting data were analyzed using the Pearson Product Moment Correlation Statistics. The findings revealed that wrong reading approaches, learners' non-involvement in extensive reading and teachers' instructional techniques significantly relate with the reading competence of learners in Nigerian primary schools or the basic education level. Based on the findings, the study recommended among other things that teachers should diversify and improve on their instructional techniques to meet the current objectives of the Millennium Development Goals.
\end{abstract}

Index Terms — reading, reading skills, beginning readers

\section{INTRODUCTION}

In the Nigerian society, the acquisition of literacy and oracy skills guarantee success, acceptance, employment and interaction with Nigerians from other linguistic groups. A few Nigerian children attend private nursery/primary schools while the majority attend public primary schools which lack adequate and functional instructional materials and facilities that would enhance teachers' and pupils' reading activities (Ekpo, Udosen, Afangideh, Ekukinam \& Ikorok, 2007). This impedes the development of reading skills in public schools and constitutes a setback in the achievement of the nation's Millennium Development Goals.

The primary school is that point at which proper foundation should be established for the acquisition of basic literacy and numeracy skills. These skills are derived from the process of reading as reading skills dictate performance in other disciplines. Reading, according to Soneye (2000), is the principal tool which children must have in order to effectively apply all other essential skills so as to comprehend what they read.

Today, learners' lack of proficiency in reading and writing and even in spoken English has created serious social and academic problems. Soneye (2000) observed that English expressions used by learners at almost all levels of education in Nigeria presently are filled with very poor articulation of words, grammar and meaning. One of the factors blamed for this problem is usually poor attitude towards reading by both learners and their teachers. However, the causes of poor reading skills development are multi-faceted. Etuk (2005) observes that learners' reading habits and their lack of involvement in extensive reading, teachers' instructional techniques and government's unstable national language policy are possible causes of poor reading culture among young school learners.

However, the importance of a right reading skill if adopted at the primary school level by learners cannot be overemphasized, especially in this era of the Millennium Development Goals. MDG requires that each child should be functionally literate and be able to communicate effectively. Functional literacy means that individuals can read with understanding and be able to apply knowledge gained to solve life's problems. Functional literacy does not just stop at learning, but ensures reading for survival even when a child's academic endeavour terminates at the primary school level (Omojuwa, 2005). A child learning to read encounters the difficulty of either reading by ear or by eye. This implies that the child does not need to sound the words, i.e. to hear what he reads before he can make meaning. This process is called vocalization (or sub-vocalization, depending on the loudness of the vocalization) and it is a poor reading approach for beginning readers and even for advanced readers at any level of education. Ekah (2005) views vocalization as the reader quietly pronouncing the words in the sentence while attempting to read. Too much emphasis 
on individual words rather than phrases and clauses reduce comprehension and Ekah warns that this poor habit impedes academic achievement of learners at all levels of education.

Also, there is a time frame for the interpretation of what comes within the eye span. The pause should be within measured time. When the eye fixation is too long, that is beyond or above the normal seconds, then the reader is fixing his eyes excessively. Ekah (2005) illuminates that during reading, the eye should see more words at a time and try to match them swiftly for comprehension to take place. Uya (2000), in the appraisal of reading habits among learners remarks that excessive eye fixation is a drawback to effective learning and academic performance.

In addition, poor readers, especially beginning readers, often engage in another wrong reading approach called regression. This is when a reader goes back on what has already been read by pushing forward and backward and distributing his trend of thought. Soneye (2000) maintains that when a reader fails to push forward until he gets to the end of the reading material, he engages in regression. The author warned that this poor habit affects reading comprehension negatively, especially for those who are just beginning to learn how to read. On the World Wide Web, there is a confirmation in this manner:

Studies have shown that the average slow reader will re-read as much as one quarter $(1 / 4)$ of a page again. Just think how this frustrates and slows you down. It's like climbing a sand dune: three steps forward and two steps backwards... like watching a DVD with your finger on a rewind button. (NWW.turboread.com/regression.htm).

It is generally accepted that most Nigerian learners at all levels do not read. This is even truer for beginning readers. Uya (2000) states that very few read for pleasure, while some only read when there is an examination or interview for a job. Yet Ekah (2005) views extensive reading by learners as a panacea for poor academic performance. Extensive reading utilizes certain skills useful and necessary for comprehension. The skills so utilized are adopted in various reading materials. Udofot (2007) states that extensive reading develops communicative competence because it enhances vocabulary development, improves interpretative ability in addition to increasing reading rate. In line with this, Ekah (2000) submits that:

A student who reads newspapers, magazines, novels and other literature for the sake of interest and knowledge is engaged in extensive reading. The reading is done for the gist of the text, that is getting the general idea or picture of the text. It equally involves reading for required information like looking for an answer to a specific question. (p.170)

To meet the demands of the objectives of the millennium development goals project, the teacher of beginning readers especially at the primary school must be involved actively in inculcating the habit of extensive reading in his learners. He should keep a record of his learners' progress in reading; this practice will engender competitiveness among his learners as each class may want to maintain the lead or improve upon their performance by reading as many books as possible (Ahmad, 2004; NTI, 2010).

Reading is one of the basic skills which a learner should acquire in the English language at the primary school level which is the beginning reading level in view of other learning tasks to which the learner will be exposed throughout his academic period at the primary school. It is highly essential to teach the learner the different skills of reading available in English and also the purposes for which we read which include getting pieces of information, understanding the ideas of others, editing our works and those of others as well as acquiring knowledge. At the primary school level, the purposes of getting information and understanding the ideas of others are common in the upper classes. In the lower classes, however, letter identification, word reading and sentence reading are the common features (NTI, 2007). In line with Millennium Development Goals, therefore, primary school pupils or beginning readers must be well groomed in all the skills of reading, and the teacher must equally be able to master the appropriate methods of handling them, e.g. intensive and extensive reading as well as skimming and scanning.

The teacher is an important component of the learning environment called school. Bamgbose (2001) maintains that the competence of a teacher enables him to fulfill the requirements of being knowledgeable with necessary resources and also enables his learners to be familiar with specific techniques which he, as a reading teacher should pass on to the learner as tools for reading achievement. Commenting on teachers' instructional techniques, Etuk (2005) equally maintains that a reading teacher must decide how he wants to get the learners to derive maximum satisfaction and pleasure from the art of reading. The author went on to add that the teacher may decide to begin the reading lesson with the discussion of a picture, a familiar illustration, questions and answers, pattern reading or reading practice.

Furthermore, to encourage beginning readers, the teacher should not allow only good readers to read in class as there would be the tendency that poor readers will become poorer and discouraged and frustrated. The poor readers should also be encouraged to read in class as this will give the teacher the opportunity to know their areas of weaknesses and help them as they learn to read (Bamgbose, 2001). Also, the teacher should always serve as a reading model to the learners by reading the materials first for the learners to listen to. In so doing, the pattern of reading is manifested while he reads covering such areas as correct pronunciation, making right pauses, observing punctuation marks, observing stresses and intonations. By the time the teacher asks the learners to read, they would draw on the teacher's performance and endeavour to read like him thus laying the right reading foundation for the beginners.

Certain authorities condemn poor instructional techniques of reading teachers. For instance, Afolayan in Bamgbose (2001) opines that a good teacher should be able to identify backward readers in the class and group them during reading. He should tolerate their weaknesses by demonstrating a certain degree of understanding. This will help the beginners and steer them in the right direction as they learn to read. Also seen as a poor reading instructional technique 
by teachers is the fact that teachers only talk and do not use the chalk to write. These poor instructional techniques impede effective achievement of young learners at the primary school (Bamgbose, 2001; Etuk, 2005; Omojuwa, 2005; UBE, 2011). In a reading class, the authors advise that it is not enough to give oral explanations to new words, phrases, sentences and certain ideas expressed without writing them out on the board; after all, the teaching profession has been described as a profession of "talk and chalk" and not talk alone. This study is therefore poised to investigate how reading skills development enhances academic achievement of beginning readers in the present era of Millennium Development Goals in Nigeria.

\section{THE STUDY}

Research and experience have demonstrated over and over again that there is a close relationship between language competence and educational attainment. The implication of this is that learners' mastery of the language of classroom communication is a basic requirement for effective learning. This includes the ability to decipher meaning from print whether on the board, paper, classroom walls or note books. But as Oyetunde and Muodumogu (1999) note, "reading is one area that is particularly problematic for children within the school system. A great majority of them are failing to learn to read and many more are unable to read to learn" (p.16). This pathetic situation could easily be attributed to ignorance of what reading is, poor methodology of teaching reading as well as inadequate preparation of reading teachers, among many other factors.

What then is reading? Reading is one of the four language skills that exist. The others are listening, speaking and writing. The language skills are further sub-grouped into oracy and literacy skills. Whereas listening and speaking are oracy skills, reading and writing are literacy skills. It is little wonder then that one is described as literate only when he can read and write.

Again the four language skills are further categorized into productive and receptive skills. Listening and reading are receptive skills, that is, avenues or means by which we take in or receive information. Speaking and writing on the other hand are productive skills, that is, avenues or means by which we produce information for others to consume (Enighe, Galadima \& Surma, 2013). According to Enighe, Galadima and Surma (2013), listening is "paying attention with the intention of having or producing the desired or intended result of communication while speaking is producing meaningful sounds" (p.98). On a general note then, reading is simply making meaning out of print and writing is producing meaningful print.

In the view of Enighe (2010), reading is a process by which information is obtained from print and which involves interaction or negotiation between the reader and the material being read. The ultimate goal of reading is comprehension; therefore reading without comprehension is like "eating without digestion". In the words of Oyetunde and Muodumogu (1999),

Reading is a meaning searching and meaning getting activity where the reader is never passive. Rather, he is actively constructing information making use of textual cues in conjunction with the information (about language, context of text and knowledge of the word generally) stored in his head. (p.19)

Furthermore, Oyetunde (2015) elucidates on the concept of reading by stating that

Reading is a process of meaning construction. ...the reader uses the information in the text and in his head...The information in the text refers to the three basic language systems namely, the graphophonic system, the syntactic system and the semantic system. The information in the reader's head refers to the reader's conceptual experience and his language knowledge or proficiency. (Pp.8-9)

Reading therefore is an indispensable tool of learning in the various hierarchies of today's educational systems. The implication of this is that if one fails to read, he has failed to learn as proficiency in reading is a success indicator in the learning process.

\section{IMPORTANCE OF READING}

Reading is an activity that sets one apart as literate; it is thus a literacy skill. Its importance lies in the fact that it is a "survival tool" as one has to read sign posts, road signs, symbols and even facial expressions that tell what cannot be spoken or written. We read time, we read attitudes and behaviours, judging them as good or bad; we read meanings to actions or inactions and we also read relationships. But specifically, reading is an activity of the literate for whereas symbols, prints, signs and other forms may make meaning to the illiterate, printed words will not be meaningful to them as they will only make the intended meaning to the literate who reads them. We read examination questions in order to understand what is expected of us by the examiner and after putting down what we assume is the correct or expected responses, we read what we have written to ensure correctness.

It is also through the skill of reading that we get to know the dosage of medications we purchase off the shelf of pharmacies in cases of self-medication. The medium of reading also is a high way for information to move from print into our minds. It is therefore a great door opener for true enquirers into the world of knowledge. Many people have wondered why reading is important. According to these people, reading is very time consuming so why engage in it when there are so many other things one can do with one's time? Reading is a determinant of fundamental functionality in today's society. Filling out application or other data providing forms is a basic requirement for the literate. How then 
can this be done without reading? Day to day activities, chores or functions that literate people engage in ( and which many people often take for granted) will become sources of frustration, anger, anxiety or fear for the one who cannot read. This will then make life meaningless or unbearable.

The educated or literate would often use their certificates to search for well paying jobs that will guarantee future comfort and ease for one's self and other dependants. The big issue here is that today, many such well paying jobs require reading as part of job performance as there will be reports and memos which must be read and attended to. Inability to read would therefore disqualify one even when skills, experiences and other certificates seemingly qualify him.

Furthermore, it is through reading that we discover new things and gain access into other people's thoughts and opinions. We live in an age that over flows with information but reading is the main way we can take advantage of these information. Reading can also help to develop one's creative side. This is why after reading a book, the reader's creativity is awakened and given a little time, the reader becomes the read, because creativity is a virtue that boosts one's self esteem or self-worth. Reading which ignites it, is therefore fundamental in developing a good self image for the more constructively creative one is, the more sense of accomplishment he would have and the better will be his selfesteem.

Reading also helps to expand one's vocabulary as reading new words puts them in our minds for later use. In addition, good reading skills, especially in a phonics reading program, improves spelling. As one encounters new words in his reading experience, he does not only grow his vocabulary account, but he also learns how to spell the new word(s) and how to use it (them) in context.

Finally, a person who knows how to read can educate himself almost totally, in any area of life they are interested in. Self-tuition, distance learning and the open-university systems are all possible and only available to readers as nonreaders cannot survive in these endeavours. As they say. "reading maketh a man" and the converse is equally the case non-reading unmakes a man or non-reading does not make a man.

\section{PROBLEMS OF READING}

Reading as a concept and as a skill is bedeviled with many problems. The problems are so many that no one writing can effectively accommodate all of them. However, a few of the problems will be discussed here. The first problem is the lack of understanding of the fact that there is a world of difference between teaching English as a school subject and teaching reading. This confusion makes some English language teachers to think that they are teaching reading when they teach English. In fact, in a great majority of Nigerian primary schools, reading does not feature on the time-table. If it is not on the time-table, the grave and sad implication is that it is never taught. The reason why it is not taught is because many people believe it can be 'caught' in the course of general English language teaching. As such, they believe that anybody who has gone through a general English class should not just know how to read but be an excellent reader. The assumption is that anyone who can speak English can read it.

Associated to the lack of distinction between teaching English and teaching reading is ignorance of what reading is. To understand what reading is, one needs to understand first what reading is not. Reading is not mouthing words; it is not head-turning; it is not finger pointing nor is it explicit eye movement. It is not vocalisation or sub-vocalisation. Reading is constructing meaning from printed matter using the information in the text and in one's head as building blocks. Reading may also mean the ability to correctly pronounce words in a printed material in order to make meaning out of the material.

When reading is misunderstood, it will be wrongly taught. The misteaching of reading is reflected in reading instructional activities tending to be "an exercise in 'reciting' passages from books with little or no comprehension" (Umolu, 1997). According to Oyetunde and Muodumogu (1999), the problem of wrong reading as a result of misunderstanding of what reading is may be observed in

memorizing and reciting the letters of the alphabet, letter naming and blending to pronounce words (a feature of alphabetic spelling method), choral reading after the teacher and some form of phonics (phonemic awareness) instruction. These essentially represent teachers' approaches to helping children learn to read. (p.17))

The misunderstanding of what reading is, is also what is responsible for misteaching reading as testing teaching. This is reflected in the English teacher asking the students in his class to engage in silent reading after which he asks them questions after explaining what he thinks are words that are beyond his learners' vocabulary level.

The fall-out of teaching reading in the ways described is that instead of instilling in learners a love for reading, a strong hate for reading will be cultivated, making wrong methodology or approach to the teaching of reading counterproductive. The few learners who may not completely hate reading may find it very frustrating as no clear effort is made by their teacher to develop in them specific reading skills or making reading a gainful exercise.

Furthermore, not many educated Nigerians read or love to read. As such, children who desire to imbibe the skill of reading find no models to copy from. Where they find one or two people who encourage them to read, the reading materials are not entirely available or where they are available they are grossly insufficient in quality and quantity to go round. Yet the basic objective of formal education to the National Policy on Education (NPE, 2014) is to develop "permanent literacy and ability to communicate effectively" (p.11). 
For reading to be effectively taught and learnt, teacher training curricula for all the levels of Nigerian educational systems, should deliberately include courses on reading geared towards equipping would be teachers with not just the principles of teaching reading but workable and result oriented approaches to the impartation of the skills of reading.

Teachers should also be motivated and re-motivated as against the de-motivation being experienced presently. Motivation and re-motivation can come in the form of in-service training opportunities, professional development programmes, prompt payment of salaries, promotion when due and better working conditions, among other things.

Again, the old system of supervision and monitoring should be brought back. This is because when supervision and monitoring are not effective, the expected outcomes of a programme will be elusive no matter how well intended or planned. What obtains today is a near or total absence of effective supervision of teachers' real classroom activities as what teachers put down in their lesson notes is not really what happens in class. Supervision and monitoring are the heart of implementation; so for teachers to effectively teach reading, they ought to be supervised and closely monitored.

To effectively teach reading, teachers must also have a good understanding of what reading is as well as clearly defined goals and objectives for every reading lesson they teach. The teacher should also ensure that he is a reader and therefore a model to his students for only readers can effectively teach reading - one cannot give what one does not have.

\section{Purpose of The Study}

The main purpose of this study was to investigate how reading skills development at the primary level relates with the academic achievement of beginning readers in primary schools. Specifically, the objectives of the study were to:

1. Determine the relationship between wrong reading approaches and pupils' academic achievement;

2. Examine the relationship between learners' involvement in extensive reading and academic achievement at the beginning reading level.

3. Determine the relationship between teachers' instructional techniques and the academic achievement of beginning readers.

\section{RESEARCH HYPOTHESES}

At 0.05 level of significance, the following null hypotheses were tested:

1. There is no significant relationship between wrong reading approaches and the academic achievement in reading of beginning readers in the primary schools.

2. There is no significant relationship between pupils' involvement in extensive reading and their academic achievement at primary schools.

3. There is no significant relationship between teachers' instructional techniques and competence in reading of beginning readers in primary schools.

\section{METHOD}

The study employed a simple survey design, while the area of study was Abak Local Government Area (L.G.A.) of Akwa Ibom State, Nigeria. The population comprised all primary $4-6$ pupils in public primary schools in Abak L.G.A. A sample of 200 pupils were drawn through a stratified random sampling technique from a total population of 815 pupils from 15 schools. The instrument used for data collection was developed by the investigators, and comprised a 12-item questionnaire and measured pupils' wrong reading approaches, pupils' involvement in extensive reading approaches and teachers' instructional techniques. Respondents were required to rate their responses on a four-point likert scale of Strongly Agree $(\mathrm{SA})=4$; Agree $(\mathrm{A})=3$; Disagree $(\mathrm{D})=2$ and Strongly Disagree $(\mathrm{SD})=1$. The instrument was administered personally by the researchers to the respondents during school hours with two schools covered each day.

Result

TABLE 1:

RESPONSES OF WRONG READING APPROACHES AND PUPILS' ACADEMIC ACHIEVEMENT IN READING

\begin{tabular}{|c|c|c|c|c|c|c|c|}
\hline Variables & $\wedge x_{1} \wedge y$ & & $a x^{2} 1 \wedge y^{2}$ & \$xy & r-cal & r-crit & Decision \\
\hline $\begin{array}{l}\text { Involvement in Wrong } \\
\text { Reading Approaches (y) }\end{array}$ & 567 & & 1825 & 13573 & \multirow[t]{2}{*}{0.260} & \multirow[t]{2}{*}{0.1965} & \multirow[t]{2}{*}{ *Significant } \\
\hline Pupils' Achievement (x) & & 4869 & & 127867 & & & \\
\hline
\end{tabular}

The results on Table 1 show that for wrong reading approaches, the calculated r-value is 0.260 while the critical rvalue is 0.195 at 0.05 level of significance and 198 degree of freedom. The null hypothesis was rejected in favour of the alternate. This means that there is a significant relationship between wrong reading approaches and the academic achievement in reading of beginning readers in primary schools. 
TABLE 2:

\begin{tabular}{|c|c|c|c|c|c|c|c|}
\hline Variables & $\wedge x_{1} \wedge y$ & & $\Delta x^{2} 1 \wedge y^{2}$ & A $x y$ & r-cal & r-crit & Decision \\
\hline $\begin{array}{l}\text { Involvement in Wrong } \\
\text { Reading Approaches (y) }\end{array}$ & 677 & & 1903 & 14578 & \multirow[t]{2}{*}{0.476} & \multirow[t]{2}{*}{0.195} & \multirow[t]{2}{*}{ *Significant } \\
\hline Pupils' Achievement (x) & & 4869 & & 138676 & & & \\
\hline
\end{tabular}

The values in Table 2 indicate that the calculated $r$-value is 0.476 , while the critical $r$-value is 0.195 at 0.05 level of significance and 198 degree of freedom. The calculated r-value is noticed to be greater than the table value; therefore, the null hypothesis is rejected in favour of the alternate. The study therefore concluded that learners' involvement in extensive reading approaches significantly relate with their academic achievement in reading.

TABLE 3:

RESPONSES OF TEACHERS' INSTRUCTIONAL TECHNIQUES AND PUPILS' COMPETENCE IN READING

\begin{tabular}{|c|c|c|c|c|c|c|}
\hline Variables & $A x_{1} \wedge y$ & $\Delta x^{2} 1 \wedge y^{2}$ & Axy & r-cal & r-crit & Decision \\
\hline $\begin{array}{l}\text { Involvement in Wrong } \\
\text { Reading Approaches (y) }\end{array}$ & 542 & 1782 & 13073 & \multirow[t]{2}{*}{0.257} & \multirow[t]{2}{*}{0.195} & \multirow[t]{2}{*}{ *Significan } \\
\hline Pupils' Achievement (x) & 4869 & 127171 & & & & \\
\hline
\end{tabular}

Table 3 shows that the calculated $r$-value is 0.257 , while the critical $r$-value is 0.195 . Since the calculated $r$-value is greater than the critical $r$-value, the null hypothesis is rejected in favour of the alternate at 0.05 level of significance. This means that teachers' instructional techniques significantly relate with pupils' competence in reading.

\section{DISCUSSION}

Results of the data analysis on Table 1 revealed that there is a significant relationship between reading approaches and beginning readers' academic achievement. This implies that pupils who apply wrong reading approaches while learning to read, stand the risk of non-mastery of the content of all subjects across the curriculum. The result is consistent with the findings and submissions of Soneye (2000), Uya (2000), Etuk (2005) and World Wide Web (2014) that wrong reading techniques such as vocalization and sub-vocalization, excessive eye fixation, regression and word pointing constitute serious inhibitions to reading achievement and affect learners' academic achievement.

Furthermore, results of findings on Table 2 confirm that learners' involvement in extensive reading have a significant relationship with their academic achievement at the primary school level which is the beginning reading level. The result establishes that learners' non-involvement in extensive reading paves a way to very poor academic achievement at any level. The results are also in support of earlier findings by Ahmad (2004), Ekah (2005), Udofot (2007) and NTI (2010), who concluded that extensive reading develops communicative competence, enhances vocabulary development, improves interpretative ability in addition to increasing reading rate, and therefore enhances effective academic achievement among young learners.

Finally, the results of findings on Table 3 indicate that there is a significant relationship between teachers' instructional techniques and pupils' competence in reading. This means that young learners who are taught by a reading teacher who diversifies his strategies to accommodate good and poor readers stand the chance of better academic achievement at any level, especially at the foundation level which is the level at which they begin to read. The findings agree with the conclusion of Bamgbose (2001), Etuk (2005), Omojuwa (2005), NTI (2007) and UBE (2011), that poor instructional strategies impede effective academic achievement of young learners at the primary level.

\section{DeVEloping READING SKILLS IN BEGINNING READERS}

To effectively and successfully develop and sustain reading in beginning readers, reading should be taught in stages and not lump sum. Oyetunde (2015) suggests five stages as follows:

(a) Oral language foundation stage which is the foundation of reading success. At this stage, beginning readers are first of all given an opportunity to understand and speak the English language preparatory to meaningful reading and writing.

(b) Print awareness stage: This is the stage where children who are beginning readers are taught that graphic symbols are meaningful and that books give meaningful and enjoyable information. Beginning readers are also taught that the pages of books are to be turned over from right to left and that books have a top and a bottom.

(3) Word recognition stage: At this stage, beginning readers are helped to acquire sight words. In Oyetunde's (2015) words,

sight words are individual words that pupils can recognize instantly at sight - this means that they can pronounce these words and they know their meanings. (p.95)

(d) Phono-phonemic awareness stage: At this stage, beginning readers are taught that letters represent sounds that are blended together and that individual sounds and groups of sounds can be combined to form words. 
(e) Comprehension stage: At this stage the learners are no longer learning to read but reading to learn. They are thus helped to understand and acquire specific comprehension skills such as understanding main ideas, making inferences, summarization and the use of context clues. This way, the learner will be helped to appreciate reading as communication.

\section{CONCLUSION}

Based on the findings of the study, the investigators concluded that for effective achievement of the objectives of the Millennium Development Goals at the basic education level, variables like proper reading approaches, learners' involvement in extensive reading and proper teaching strategies are significantly of utmost importance.

It is also the conviction of the authors that if the steps presented in this paper are followed, developing reading skills in beginning readers will no longer be a walk in the dark. The learners will love to read and the teachers will rejoice at the fruit of their travail.

\section{RECOMMENDATIONS}

Based on the findings of the study, the following recommendations are hereby made:

1. Teachers need to adopt diversified instructional strategies in their approach to teaching reading and this should be done at an early stage or primary school level, which is the stage of beginning reading.

2. The conventional classroom method of teaching reading should be discouraged through the provision of reading materials and objects that stimulate learners' interest in reading.

3. Teachers of beginning readers, especially at the basic education level should eschew wrong reading practices and quickly correct them in learners.

4. Individual differences in children's reading ability should be identified and properly addressed through variation of reading techniques.

5. Beginning readers should be encouraged to read materials outside the recommended classroom texts by parents and teachers as well.

\section{REFERENCES}

[1] Ahmad, A. (2004). Developing a result-oriented reading habit. Journal of Literacy and Reading in Nigeria, 10 (1), $285-291$.

[2] Bamgbose, A. (2001). Models of communication in multilingual states. West African Journal of Modern Language, 3(20), 6065

[3] Ekah, M.H. (2005). Approaches to English language teaching. Uyo: Inela Ventures.

[4] Ekpo, C.M.; Udosen, A.E.; Afangideh, M.E.; Ekukinam, T.U. \& Ikorok, M.M. (2007). Jolly phonics and the ESL pupils' reading development: A preliminary study. Journal of Research and Development in Education (JORDE), 3(2), 1-14.

[5] Enighe, J-M, Galadinma, J. D. \& Surma, R.I. (2013). Business communication for schools and colleges. Abuja: YaByangs publishers.

[6] Enighe, J-M. (2000). A contrastive analysis of the noun phrase in English and Olulumo languages: Implications for the teaching of English. Unpublished Ph.D dissertation of the University of Jos.

[7] Etuk, G.K. (2005). Investment in children's education: Nurturing reading interest in pre-primary/primary school children by parents. Journal of Applied Literacy and Reading, 2, 125-135.

[8] Federal Government of Nigeria/UBE (2011). Federal teachers' scheme, capacity building- phonics and oral English. Abuja: Universal Basic Education Commission.

[9] Federal Government of Nigeria. (2014). National policy on education. Lagos: Federal government printing press.

[10] National Teachers' Institute. (2007). Manual for the re-training of primary school teachers of English language. Kaduna: NTI Press.

[11] National Teachers' Institute. (2010). An NTI-TESSA INTEGRATED manual for the re-training of primary school teachers. Kaduna: NTI Press

[12] Omojuwa, J. (2005). Laying a strong foundation for higher level reading achievements: Problems and prospects. Journal of Applied Literacy and Reading, 2, 7-15.

[13] Oyetunde, T.O. \& Muodumogu, C.A. (1999). Effective English teaching in primary and secondary schools. Jos: Conference on Education and Improvement (CEI).

[14] Oyetunde, T.O. (2015). Olu, Musa and Eze cannot read: Arresting the drift towards basic and higher illiteracy. $69^{\text {th }}$ inaugural lecture series of the University of Jos.

[15] Soneye, S. (2000). Reading for academic purposes. Ibadan: University Press.

[16] Udofot, I.M. (2007). English and the Nigerian situation: Trends and imperative. Uyo: Univeristy Press.

[17] Umolu, J.J. (1997). Reading and reading instruction at the primary and secondary school levels: State of the art and strategies for improvement. In T.O. Oyetunde, J.S. Aliyu, A. Nwoke \& A.F. Miri (Eds). English teaching improvement. 1-14. Jos: LECAPS.

[18] Uya, M. (2000). A question of reading. London: Methuen and Co.

[19] World Wide Web. (2014). Speed reading technology. Retrieved from www.turboread.com/regression.htm on 19 th Oct., 2014. 
Jeno-Mary Enighe is an Associate Professor of English Education in the Faculty of Education in the University of Jos. A renowned personality in the area of language teaching and communication, Jeno-Mary holds a Ph.D in English Education from the University of Jos, Nigeria. She has to her credit over sixty (60) publications in highly rated journals both nationally and internationally. Jeno-Mary hails from Ikom LGA of Cross River State and is presently lecturing at the University of Jos, Faculty of Education, Department of Arts Education (English Unit). She teaches undergraduate and post graduate students, supervises projects and engages in research.

Maria Emmanuel Afangideh is a Senior Lecturer with the University of Uyo, Nigeria. She holds a Ph.D in Language Education from the University of Nigeria, Nsukka. Maria is very widely published with over fifty five (55) publications in learned journals across the world. She is from Obot Akara LGA of Akwa Ibom State, Nigeria and is presently lecturing at the University of Uyo, Akwa Ibom State. Maria is married to Emmanuel Afangideh and together they have three (3) wonderful boys. 